\title{
POLYSACCHARIDES AND BACTERIAL PLUGGING
}

\section{Cooperative Agreement DE-AC22-90BC14664.000}

\author{
The University of Michigan \\ Ann Atbor; Michigan
}

Contract Date: July 11990

Anticipated Completion: June 301993

Funding for FY 1990: $\$ 50000$

\section{Principal Investigator:}

H. Scott Fogler

Project Manager:

Edith Allison

Bartlesville Project Office

\section{Reporting Period; April 1- June 30, 1991}

\section{DISCLAIMER}

This report was prepared as an account of work sponsored by an agency of the United States Government. Neither the United States Government nor any agency thereof, nor any of their employees, makes any warranty, express or implied, or assumes any legal liability or responsibility for the accuracy, completeness, or usefulness of any information, apparatus, product, or process disclosed, or represents that its use would not infringe privately owned rights. Reference herein to any specific commercial product, process, or service by trade name, trademark, manufacturer, or otherwise does not necessarily constitute or imply its endorsement, recommendation, or favoring by the United States Government or any agency thereof. The views and opinions of authors expressed herein do not necessarily state or reflect those- of the United States Government or any agency thereof.

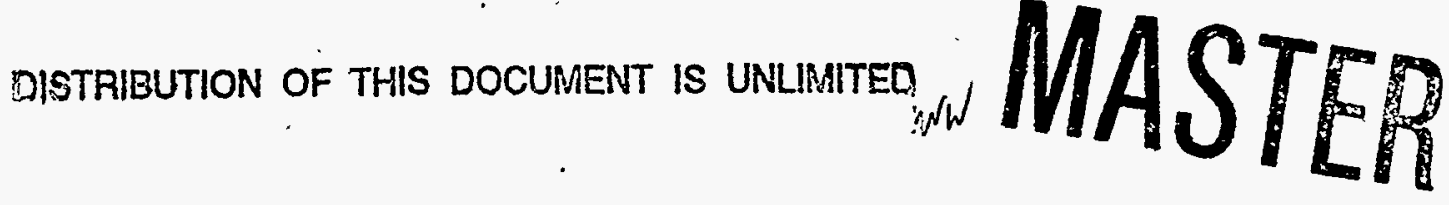




\section{DISCLAIMER}

Portions of this document may be illegible in electronic image products. Images are produced from the best available original document. 


\section{Objective}

The objectives of this research are to elucidate and model bacterial transport in porous media, to determine the importance of polysaccharides bridging as a retentive mechanism, and to identify key parameters that influence porous media plugging.

This project has been subdivided into three tasks: Task 1 is the determination of the growth kinetics of the Leuconostoc bacteria and how they are affected by 1) the nutrient feed, and 2) surface effects; Task 2 will quantify the importance of polysaccharide production as a cell retention mechanism; and Task 3 is the elucidation of the rate of polysacchatide production and the combined effect that polysaccharide production and cell growth has upon plugging.

\section{Summary of Technical Progress}

Batch growth experiments have been conducted to determine the rate of polysaccharide production (dextran) during cell growth. In addition, culture studies have been conducted for the verification of the growth model.

\section{Effect of Yeast Extract Concentrations on Cell Growth}

The further verification of the two parameter model, as presented in the past quarterly teports, was the focus of these batch experiments. Three series of batch culture experiments, labelled as experimental series $\mathrm{KE}-20, \mathrm{KE}-21$ and $\mathrm{KR}-23$, were conducted with varying yeast extract concentrations and with no saccharides. These experiments were conducted according to the procedure detailed in earlier quarterly reports, with the exception that the inoculum comprised of cells directly cultivated from a stock cultures purchased from ATCC 14935, ie. new inoculum. Cells used in the past kinetic experiments were originally from a stoak of ATCC 14935 cells However, they were continuously cultivated as inoculum for the past kinetic experiments, ie. a cultured inoculum.

The results from these experiments and the past growth experiments having yeast extract as the sole substrate are presented in Table 1. As can be seen, the specific rate constants for the cells for the new inoculum are higher thar the rates found from the past experiments using cultured cells as inoculum. This indicates that the cells used in the original experiments have undergone a phenotypic alteration. Thus, the model developed could not be verified and requires additional data. In future experiments, the growth of the inoculum will be controlled by minimizing the number of cell transfers before use in kinetic expériments.

\section{Bolysaccharide Production}

Two additional experimental series have been completed to determine the rate of cellular production of dextran. The first set of experiments consisted of two batch reactors containing 5 and $36 \mathrm{~g} / \mathrm{L}$ of sucrose and $10 \mathrm{~g} / \mathrm{L}$ of yeast extract in each. These reactors were inoculated with cells that were continuously cultured as discused earlier. The second experimental series consisted of cells grown in feed containing $5,10,30$ or 50 g sucrose/L. and $10 \mathrm{~g}$ yeast extract $/ \mathrm{L}$. The inoculum used in the second sertes of experiments were new colls. In both series the respective inoculums were grown in a glucose-fructose foed for a 
24 hour period, centrifuged, and then resuspended in their respective feed at the time of inoculation.

Table 1. Specific growth rate as determined by batch cultures.

\begin{tabular}{|c|c|c|c|c|c|c|}
\hline \multirow{2}{*}{$\begin{array}{l}\text { Yeast } \\
\text { Extract } \\
\text { Conc. } \\
\text { (g/L) }\end{array}$} & \multicolumn{5}{|c|}{ Experimental Series } & \multirow[b]{2}{*}{$\mathrm{KE} 23$} \\
\hline & KE 09 & $\begin{array}{r}\text { KE } 11 \\
\text { Sped }\end{array}$ & $\begin{array}{l}\text { KR } 16 \\
\text { c Growth }\end{array}$ & $\begin{array}{l}\mathrm{KE} 20 \\
\mu\left(h r^{-1}\right)\end{array}$ & $\mathrm{KE} 21$ & \\
\hline $\begin{array}{c}1 \\
5 \\
10 \\
20 \\
30\end{array}$ & 0.205 & $\begin{array}{l}0.046 \\
0.332\end{array}$ & $\begin{array}{l}0.105 \\
0.208\end{array}$ & $\begin{array}{l}0.551 \\
0.596 \\
0.555\end{array}$ & $\begin{array}{l}0.506 \\
0.548 \\
0.864 \\
0.713\end{array}$ & $\begin{array}{l}0.45 \\
0.55 \\
0.630 \\
0.680\end{array}$ \\
\hline
\end{tabular}

Note that Experimental series $\mathrm{KE} 09$, $\mathrm{KP} 11$, and $\mathrm{KE} 16$, were inoculated with cells that were continuously cultured.

Cellular dextran production was determined by using the phenol-sulfuric assay 1 , while cell counts where determined by Culture Counter, as detailed in the last report. Figure 1 illustrates a growth curve and dextran production curve for cells grown in a feed containing $36 \mathrm{~g} / \mathrm{L}$ sucrose and $10 \mathrm{~g} / \mathrm{L}$ yeast extract. The curve demonstrates a lag between dextran production and cell growth, with cells growth always preceding polymer production. This result was typical for all batch experiments. The difference in the duration of time before dextran production and after cell growth indicates that dextran synthesis is a Type III product as typified by Ganden, 2 Type III products are known to be produced only when cells reach maturity. Hence the difference between the growth lag and the dextran synthesis lag is the time require for the cell to reach maturity. The corresponding growth rate, growth lag, dextran synthesis lag, and final dextran yields are presented in Table 2.

Two interesting results are presented by the data which should be discussed. The first being the ability of the cells to produce dextran after reaching maturity. Note that time required to teached maturity depends on the concentration of sucrose in the feed. However, at this time there does not seem to be any correlation between the length of this - maturity period and the sucrose concentration. The second result is the difference in the cell growth rate and final dextran production yields when inoculated with continuously cultured cells or new cells. The cell's growth rate for both types of inoculums were found to depend on the suctose concentration in the feed; the rates for the continuously cultured cells were comparatively lower. The lower cell growth rates were accompanied by an increase in the final dextran production yields. This result is expected since cell production and dextran synthesis are competing for sucrose for growth. Hence, even though the data from past experiments inoculated with continuous cultured cells can not be used to model the cells growth, because the cell's have undergone a phenotypic alteration, the data does provide us with information with respect to the ability of manipulating the feed and cells to control the cell's ability to produce polysaccharides. This manipulation will possibly enable us to eventually influence cell transport in porous media by controlling polysaccharide production relative to cell production. 


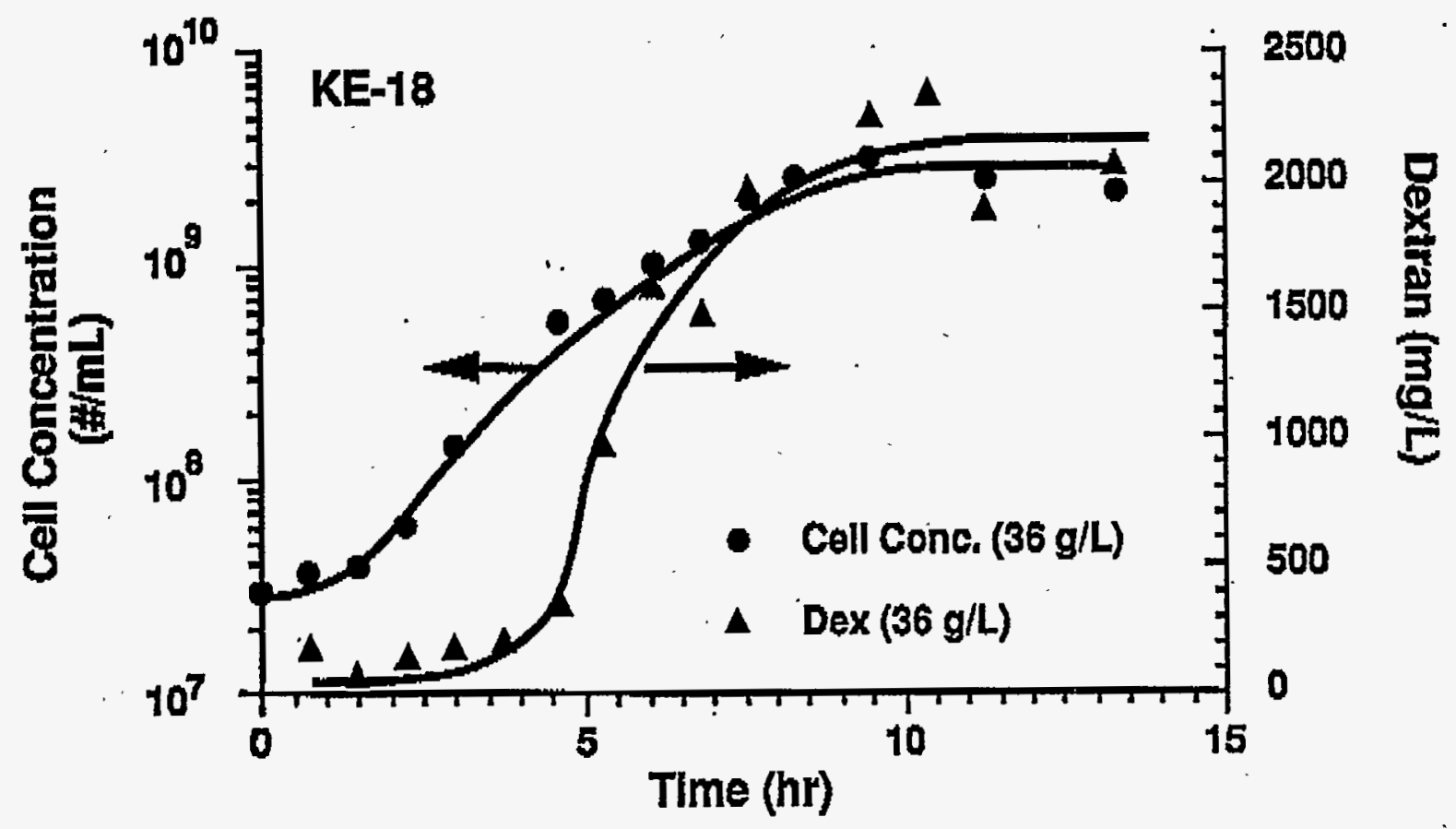

Figure 1. The resulting cell and dextran concentration when Leuconostoc cells are inoculated into a media containing $36 \mathrm{~g}$ sucrose $/ \mathrm{L}$ and $10 \mathrm{~g}$ yeast extract/L.

Table 2. Cellular growth rate, growth lag, dextran synthesis lag, and final dextran yields as a function of initial suctose concentration.

\begin{tabular}{|c|c|c|c|c|}
\hline $\begin{array}{l}\text { Sucrose } \\
\text { Conc. } \\
(g / L)\end{array}$ & $\begin{array}{c}\text { Specific } \\
\text { Growth } \\
\text { Rate }(\mu) \\
\left(h^{-1}\right)\end{array}$ & $\begin{array}{l}\text { Growth } \\
\text { Lag } \\
\text { (hr) }\end{array}$ & $\begin{array}{l}\text { Maturity } \\
\text { Time } \\
\text { (hr) }\end{array}$ & $\begin{array}{c}\text { Final } \\
\text { Dextran } \\
\text { Conc. } \\
(\mathrm{mg} / \mathrm{L})\end{array}$ \\
\hline \multicolumn{5}{|c|}{ Inoculum - cultured cells } \\
\hline $\begin{array}{l}5 \\
20 \\
36 \\
\end{array}$ & $\begin{array}{l}0.684 \\
0.782 \\
0.746\end{array}$ & $\begin{array}{l}1.2 \\
1.4 \\
1.1 \\
\end{array}$ & $\begin{array}{l}1.9 \\
2.7 \\
2.6 \\
\end{array}$ & $\begin{array}{r}200 \\
2200 \\
2200 \\
\end{array}$ \\
\hline \multicolumn{5}{|c|}{ Inoculum - new cells } \\
\hline $\begin{array}{l}5 \\
15 \\
30 \\
50\end{array}$ & $\begin{array}{l}0.649 \\
0.832 \\
0.907 \\
0.782\end{array}$ & $\begin{array}{l}0.27 \\
0.9 \\
0.89 \\
0.51\end{array}$ & $\begin{array}{l}2.73 \\
2.1 \\
1.6 \\
4.5\end{array}$ & $\begin{array}{c}138 \\
522 \\
700 \\
1333\end{array}$ \\
\hline
\end{tabular}




\section{References}

1) Chaplin, M.F, and J.F. Kennedy, Carbohydrate AnaIysis, IER Press, Oxford England 1986

2) Bailey, James E, and David F. Ollis, Biochemical Enginceting Fundamentals, MeGraw Hill Book Co., 1977 